\title{
Adverse drug reactions associated with successful treatment of multidrug-resistant tuberculosis patients in Cempaka Putih Islamic Hospital Central Jakarta
}

\author{
Adin Hakim Kurniawan ${ }^{1}$, Harpolia Cartika ${ }^{1}$, Siti Aisyah ${ }^{2}$ \\ 1Pharmacy Study Program, Poltekkes Kemenkes Jakarta II, Percetakan Negara 23, Indonesia \\ ${ }^{2}$ Pharmacy Installation of Cempaka Putih Islamic Hospital, Central Jakarta, Indonesia
}

\section{Keywords \\ Adverse drug reaction \\ Multi-drug resistance \\ Successful treatment \\ Tuberculosis}

\section{Correspondence \\ Adin Hakim Kurniawan \\ Pharmacy Study Program \\ Poltekkes Kemenkes Jakarta II \\ Jakarta \\ Indonesia \\ adin.hakim@poltekkesjkt2.ac.id}

\begin{abstract}
Introduction: Indonesia experiences Tuberculosis (TB) cases that are very complex and complicated, especially those dealing with Multi-Drug Resistance TB (MDR-TB). Its therapy using several types of drugs can cause several problems; one of them is an adverse drug reaction. Aim: To investigate the association between Adverse Drug Reactions (ADR) and the successful treatments of MDR-TB patients. Method: This was a retrospective study, the population in this study were all patients with medical and treatment records for MDR-TB. This sampling type is a purposive sampling technique. The statistical analysis used the chisquare test as the statistical test. Results: The significant correlation was between the incidence of $A D R s$ and successful treatment with $p=0.024$; odd ratio=2.526; $\mathrm{Cl}=1.193-17.892$. Conclusions: This study may help in formulating strategies for the timely and aggressive management of adverse drug reactions. This can reduce the deferral of therapy and increase the clinical success rate.
\end{abstract}

\section{Introduction}

In Indonesia, the Multi-Drug Resistance Tuberculosis (MDR TB) cases from early 2009 to the first quarter of 2015 were 4,731. (Emil Ibrahim, 2018). Seventy-two per cent of these patients were currently continuing their treatment, while the remaining had recovered. MDR-TB is a condition in which Mycobacterium tuberculosis is resistant to Anti-TB Drugs (ATD), namely Isoniazid and Rifampin (Mulu et al., 2015). The World Health Organization (WHO) reported that there were 290,000 cases of MDR-TB in 2011 (WHO, 2016). In addition, there are 27 high burden countries for MDRTB which represents $85 \%$ of the world burden of MDRTB. Indonesia was in ninth place on this list. Indonesia's MDR-TB cases are increasing every year (Kamso et al., 2011).

Patient's non-compliance is the major contributor to drug resistance. A number of efforts were initiated, such as providing health education to TB patients and the general public about TB as well as rational prescribing and prescription review, which includes assessment of prescribing patterns, drug interactions, and adverse drug reactions (Lange et al., 2019).

The clinical characteristics of MDR-TB are more complex than sensitive TB due to using of category I and category II TB where Category 1 was for new smearpositive patients with pulmonary TB and Category 2 was for sputum smear-positive patients who have relapsed, who have treatment failure or who are receiving treatment after treatment interruption. In principle, the management of TB uses only one regimen of TB medicines for six months, while the management of MDR-TB uses a minimum of five medicines and lasts 18 to 24 months (Yang et al., 2017). Management of MDR-TB cases is often associated with the incidence of side effects ranging from mild to severe. The rationale 
for anti-TB drug selection for accuracy is started from the most bactericidal with the lowest toxicity to highest toxicity (Jacobs, Ross, 2012; Yang et al., 2017).

MDR-TB treatment with several types of drugs will cause problems in drug potentiation, as well as side effects. The response of each individual is unpredictable, but treatment should not stop just because of fear of the reaction that arises (El-Din et al., 2015). The incidence rate of patients experiencing severe adverse events was $91.3 \%$ with line two antituberculosis drugs, and the percentage of side effects in the mild category was $84.2 \%$ (Reviono et al., 2014). It is a serious concern for patients, especially those who experience severe side effects if the monitoring of the side effects of the drug is not carried out properly (Mulu et al., 2015).

This study was conducted in Cempaka Putih Islamic Hospital, which was assigned as one of the public hospitals for treating MDR-TB patients in Indonesia. According to the data from the medical records, the number of MDR-TB patients who are under treatment is 180 patients. For MDR-TB patients treated in the hospital, it seems that the number has increased from 2016-2018. In 2016, there were two patients, and in 2017, the number increased to 7 patients until 2018; there were 15 active MDR-TB patients who were receiving treatments. This is exacerbated by patients who are drug-resistant (WHO, 2016). So, one of the efforts of the hospital to be an effective and safe treatment is by placing the patients separately from other polyclinics to reduce exposure to other patients. Based on this background, the authors are interested in research to investigate the association between ADRs and treatment of MDR-TB in Cempaka Putih Islamic Hospital in Central Jakarta in 2020.

\section{Methods}

\section{Design}

A retrospective cross-sectional study evaluating 124 patients with MDR-TB who were treated in Cempaka Putih Islamic Hospital in Central Jakarta from January 2019 to December 2019 was conducted. The outcome of interest was defined as sputum culture conversion within three months, and we have analysed its association between adverse drug reaction and the outcome.

\section{Population}

This study is originally from medical and MDR-TB treatment records of patients who were treated in Jakarta Cempaka Putih Islamic Hospital in 2019. The type of sampling was carried out on a non-probability basis sampling with purposive sampling technique. That is, determining a certain consideration or criteria that must be attained (inclusion), such as all of the MDR-TB patients who have not consumed MDR ATD ever. Secondly, there were MDR-TB patients who consumed MDR ATD regularly at least three months from the earliest treatment, and the last one is patients who have a number of years more than 17 years old and less than 70 years old, have been willing to take part in the research and have signed the informed consent. Meanwhile, the exclusion criteria in this study are patients who had a history of other lung diseases; and MDR-TB patients who discontinued MDR ATD treatment three months after initial treatment. The number of samples carried out in this study was 136 people, but those who met the inclusion criteria of these patients were 124 patients who were observed during the six months that the study was carried out.

\section{Data analysis}

The statistical analysis used was a bivariate analysis to examine the relationship between drug side effects and the outcome of MDR TB patients using the Chi-square test (Hair et al., 2010).

\section{Ethics}

The study design was approved by the ethics committee of Poltekkes Kemenkes Jakarta II and Cempaka Putih Islamic Hospital with the number LB.02.01/I/K.E./39/517/2020.

\section{Results}

Overall, 124 patients had received MDR-TB treatment with data on patient demographic characteristics consisting of 1) gender; 2) age; 3) occupation and history of comorbid diseases (see Table I).

The frequency distribution of MDR-TB patients based on gender shows that the number of male patients was greater than the number of female patients (56.45\%). Based on the age category, there was a proportion of the productive age between 18 and 59 years old, with the highest proportion at $91.93 \%$. The proportion of MDR-TB patients with a history of job status was the greatest; as much as $20.16 \%$ of the patients were with a history of employment as traders/labourers. And $32.6 \%$ of the patients were self-employed. Most of the patients' history status was in the comorbid category with other diseases percentage of $41.13 \%$ so that the most common types of comorbidity were diabetes mellitus (22.58\%) and HIV infection (7.28\%). 
Table I: Sociodemographic characteristics

\begin{tabular}{|c|c|c|}
\hline $\begin{array}{l}\text { Sociodemographic } \\
\text { characteristics }\end{array}$ & $\begin{array}{l}\text { Number } \\
(\mathrm{n}=124)\end{array}$ & $\begin{array}{c}\text { Percentage } \\
\text { (\%) }\end{array}$ \\
\hline \multicolumn{3}{|l|}{ Gender } \\
\hline - Male & 70 & 56.45 \\
\hline - Female & 54 & 43.55 \\
\hline \multicolumn{3}{|l|}{ Age } \\
\hline - Productive (18-59 years old) & 114 & 91.93 \\
\hline $\begin{array}{l}\text { - Less Productive ( } \geq 60 \text { years } \\
\text { old) }\end{array}$ & 10 & 8.07 \\
\hline \multicolumn{3}{|l|}{ Occupational } \\
\hline - Employed & 99 & 79.84 \\
\hline - Unemployed & 25 & 20.16 \\
\hline \multicolumn{3}{|l|}{ Job status } \\
\hline \multirow{2}{*}{$\begin{array}{l}\text { - Traders/Laborers/Self- } \\
\text { employed }\end{array}$} & 40 & 32.26 \\
\hline & 36 & 29.03 \\
\hline - Private employee & 23 & 18.55 \\
\hline - Government employee & 16 & 12.90 \\
\hline - Housewife & 9 & 7.26 \\
\hline \multicolumn{3}{|l|}{ - Unemployment } \\
\hline \multicolumn{3}{|l|}{ Disease status } \\
\hline $\begin{array}{l}\text { - Has no history of } \\
\text { comorbidities }\end{array}$ & 73 & 58.87 \\
\hline - Has a history of comorbidities & 51 & 41.13 \\
\hline \multicolumn{3}{|l|}{ Types of comorbidity: } \\
\hline - Diabetes mellitus & 28 & 22.58 \\
\hline - HIV infection & 9 & 7.26 \\
\hline - Hepatitis virus & 5 & 4.03 \\
\hline - Hypertension & 5 & 4.03 \\
\hline - Psychotic disorder & 4 & 3.23 \\
\hline
\end{tabular}

In Table II, it can be found that the frequency distribution of the results of the treatment and clinical characteristics of MDR-TB patients indicates the highest treatment. There are five treatment items (33.87\%), with the type of cycloserine treatment being the most prescribed (74.19\%). The most frequent ADR type in MDR-TB patients was gastrointestinal disorders in the stomach at $22.72 \%$, and the most successful treatment of MDR TB patients was in the cured category (89.52\%). In Table III, the relationship between the incidence of ADR and the outcome of success for MDR-TB patients has a significant value ( $p=$ 0.024 ; odds ratio $=2.526)$ and confidence interval $(\mathrm{Cl}$ $95 \%=1.193-17.892$ ).
Table II: Descriptive summary for all variables of treatment pattern and adverse drug reaction type

\begin{tabular}{|c|c|c|}
\hline $\begin{array}{l}\text { Treatment and clinical } \\
\text { characteristics }\end{array}$ & $\begin{array}{c}\text { Total } \\
(n=124)\end{array}$ & $\begin{array}{c}\text { Percentage } \\
\text { (\%) }\end{array}$ \\
\hline \multicolumn{3}{|l|}{ Treatment regimen patterns } \\
\hline - 2 items & 1 & 0.81 \\
\hline - 3 items & 18 & 14.52 \\
\hline - 4 items & 41 & 33.06 \\
\hline - 5 items & 42 & 33.87 \\
\hline - 6 items & 10 & 8.06 \\
\hline - 7 items & 12 & 9.68 \\
\hline MDR-TB drugs used & Item = 573 & \\
\hline - Levofloxacin & 92 & 74.19 \\
\hline - Cycloserine & 88 & 70.97 \\
\hline - Ethionamide & 72 & 58.06 \\
\hline - Clofazimine & 74 & 59.68 \\
\hline - Linezolid & 60 & 48.39 \\
\hline - Bedaquiline & 61 & 49.19 \\
\hline - Pyrazinamide & 36 & 29.03 \\
\hline - Ethambutol & 35 & 28.23 \\
\hline - Moxifloxacin & 22 & 17.74 \\
\hline - Isoniazid & 14 & 11.29 \\
\hline - Delamanid & 11 & 8.87 \\
\hline - Kanamycin & 8 & 6.45 \\
\hline \multicolumn{3}{|l|}{ Risk of ADR } \\
\hline - Has an ADR & 82 & 66.13 \\
\hline - Has not ADR & 42 & 33.87 \\
\hline \multicolumn{3}{|l|}{ Level of ADR } \\
\hline - Mild & 47 & 57.32 \\
\hline - Moderate & 23 & 28.05 \\
\hline - Severe & 12 & 14.63 \\
\hline \multicolumn{3}{|l|}{ ADR Type } \\
\hline - GI disturbance & 20 & 16.93 \\
\hline - Peripheral neuropathy & 19 & 16.13 \\
\hline - Psychiatric disorder & 15 & 12.09 \\
\hline - Central nervous system & 11 & 8.87 \\
\hline - Arthralgia, arthritis & 9 & 7.25 \\
\hline - Dermatological effects & 4 & 3.22 \\
\hline - Hyperthiroid & 1 & 0.80 \\
\hline - Ototoxicity & 1 & 0.80 \\
\hline \multicolumn{3}{|l|}{ Outcome of success MDR } \\
\hline - Getting well & 111 & 89.52 \\
\hline - Treatment Failure & 13 & 10.48 \\
\hline
\end{tabular}


Table III: Significant differences of adverse drug reactions associated with successful treatment

\begin{tabular}{|c|c|c|c|c|c|c|}
\hline \multicolumn{2}{|c|}{ Adverse drug reaction type } & \multicolumn{2}{|c|}{$\begin{array}{l}\text { Outcome of success for MDR-TB } \\
\text { patients }\end{array}$} & \multirow[t]{2}{*}{$p$-value } & \multirow[t]{2}{*}{$\begin{array}{l}\text { Odd ratio } \\
\text { (OR) }\end{array}$} & \multirow[t]{2}{*}{$\begin{array}{l}\text { Confidence Interval (C } \\
\text { 95\%) }\end{array}$} \\
\hline & & Getting well & Treatment failure & & & \\
\hline \multirow[t]{4}{*}{ ADR } & Minor ADR & 90 & 5 & 0.024 & 2.526 & $1.193-17.892$ \\
\hline & & $(72.58 \%)$ & $(4.03 \%)$ & & & \\
\hline & Major ADR & 21 & 8 & & & \\
\hline & & $(16.90 \%)$ & $(6.45 \%)$ & & & \\
\hline
\end{tabular}

Note: Minor ADR type in comparison to not major type; model-adjusted estimates of odds ratio (OR) compared to reference groups, $95 \%$ Confidence Intervals $(\mathrm{Cl})$, and associated individual significance values $(p)$ were reported.

\section{Discussion}

This study is in line with Erma's (2017) study which revealed that there was a case group of male patients diagnosed with TB that was more common in men than in women (Widiastuti et al., 2017). The high number of men suffering from MDR-TB is because they have a high level of mobility which will affect their productivity. This is what allows for a wider risk of transmission. The high number of men with a history of dropping out of treatment is due to the tendency for men to have a lower regularity of treatment than in women (Gualano et al., 2019). Characteristics of the age of MDR-TB patients are that they are mostly at reproductive age. This is in line with research conducted by Hyun-Oh Park (2016), in which the ages of patients are ranging from 14 to 42 years old. Even in the global report, the patients of MDR-TB cases are at the age of 15-55 years old (Tae Won et al., 2017), so that in the occupational status category, patients are more likely to develop MDR-TB due to being more active in studying, working, or other activities and having difficulty taking medication according to schedule due to busy work, resulting in non-adherence to treatment (Mulu et al., 2015).

Based on the results of research on comorbidities, there are comparable results between the proportion of patients who do not have a history of comorbidities and the proportion of patients who have a history of comorbidities. In Table I, there is Diabetes Mellitus as a comorbid disease in MDR-TB patients. Thus, TB patients with comorbid DM must be given clear and continuous information as well as persuasive communication about the importance of taking antituberculosis drugs routinely. Always adhere to controlling blood sugar levels is also important to keep the blood sugar remain stable and well maintained. This is because patients who have abnormally high levels of sugar (glucose) in the blood can cause impaired phagocytosis, chemotaxis, reactive oxygen species (ROS), and cell function. This can reduce the immunity of TB sufferers and can increase cases of MDR-TB (Schmit et al., 2017).
In Table II, the characteristics of the MDR-TB drug use regimen prescribed to MDR-TB patients have a pattern of two types of drugs up to seven types of drugs, The most widely used prescription is with five types of drugs, namely Levofloxacin (Lfx) + Cycloserine (Cs) + Bedaquiline $(\mathrm{Bdq})+$ Linezolid (Lzd) + Clofazimine (Cfz) for as many as 15 patients. Based on the 2016 MDR-TB treatment guide, the doctor has done it well in providing this prescribing pattern. The guidelines state that the current MDR-TB ATD alloy choice is a standardised alloy, which at the beginning of treatment will be given the same to all MDR-TB patients (standardised treatment). MDR-TB management uses a minimum of five drugs and keeps going from 18 to 24 months. The management of MDR-TB cases is often associated with the incidence of side effects ranging from mild to severe so that many patients of MDR-TB start experiencing the side effects of disrupting the course of treatment (Kemenkes RI, 2014).

Levofloxacin, a third-generation fluoroquinolone with broad-spectrum activities, including gram-positive and atypical pathogens, inhibits topoisomerase II (DNA gyrase) and topoisomerase IV, which are required by bacteria for DNA replication. These drugs form complex bonds with each of these enzymes and bacterial DNA. This inhibition produces a cytotoxic effect on the target cells (Pranger et al., 2019). Some fluoroquinolones are active against dormant and replicating bacteria. The mechanism of action of fluoroquinolones is different from other antimicrobials, such as beta-lactams, macrolides, tetracyclines, or aminoglycosides. Therefore, organisms' resistant to these antibiotics can still be sensitive to levofloxacin (D. Pranger et al., 2012).

The MDR-TB treatment has a long treatment period (18-24 months). The number of drugs used for treatment is relatively higher than that of drugsensitive TB patients. MDR-TB drugs can cause more side effects than ordinary TB drugs (Umi Fatmawati, 2019). In the study results, researchers evaluated the occurrence of ADR in 82 patients (66.13\%). However, based on the observed level of adverse drug reaction, $14.63 \%$ of the patients required serious treatment (severe category). Based on these monitoring data, those side effects still have a lower frequency than that 
of other types of side effects (mild or moderate category). So, discontinuation of therapy can be done with several other factors, for example, monitoring patients being treated for MDR-TB in the hospital, so that monitoring is needed for that, as well as stringent side effects and clinical pharmacy implementation in terms of rational drug selection (Merid et al., 2019). The side effect that occurred in the results of this study was complaints of gastrointestinal disorders (GI) disorders after MDR-TB treatment (16.13\%). This is in line with several MDR-TB treatment guidelines where gastrointestinal disturbances are most prominent after treatment with ethambutol, pyrazinamide, and paraamino salicylates.

Most GI side effects can be managed without stopping the drug, by increasing the dose, dividing the dose, or by taking antiemetics. If Gl symptoms are not severe, $\mathrm{H} 2$ receptor blocking agents, such as lansoprazole, omeprazole, or antiemetic agents, may be added to the regimen, namely ondansetron. However, if symptoms, such as nausea, vomiting, or loss of appetite, are severe, then the administration of paraaminosalicylates can be stopped (Yates et al., 2017).

Some of the drugs used for MDR-TB treatment can cause psychiatric disorders. Psychosis has been reported as a side effect of using Isoniazid (INH) ethambutol, fluoroquinolones, and cyclosporine (CS). Depressive psychosis has been reported as a side effect mainly associated with CS. It has been reported that the incidence of severe psychiatric manifestations includes hallucinations, anxiety, depression, euphoria, behavioural disorders, and suicidal thoughts or attempts to use cyclosporine drugs (Arif et al., 2017). Cycloserine, a drug with suspected psychiatric ADR, was reported in $10 \%$ of cases where the drug was already discontinued in this study. Cycloserine-related neurotoxicity is likely due to reduced central nervous system (CNS) production of gamma-aminobutyric acid caused by inhibition of glutamate decarboxylase. In most of these cases, the drug is stopped, with rapid recovery of mental status and no recurring symptoms. Psychiatric symptoms appeared within the first two months of treatment in this study (Arif et al., 2017). The increased risk of Central Nervous System (CNS) toxicity can be attributed to excessive use of the combination of the drug cyclosarin with ethambutol, isoniazid, and fluoroquinolones.

In addition to drug toxicity, psychosocial factors can influence psychological complications during MDR-TB therapy. Therefore, it is necessary to consider the patient's adherence to the treatment regimen. Various types of side effects of MDR-TB drugs can lead to the discontinuation or postponement in taking medication so that rational monitoring of drug assessment is needed.
In Table III, there is a significant correlation between the incidence of side effects of the drug with the successful outcome of patients $(p<0.05 ; p=0.024)$, so the effect of ADR events have a tendency to be 2.5 times more likely to affect the success of treatment of MDR-TB patients when compared in the absence of $A D R$ in treatment.

Another study found the successful treatment outcome profile showed that 59 cases (47.2\%) were cured at the end of treatment; among them, ADRs were seen in 43 $(72.88 \%)$. The death rate and progress to extensively drug-resistant TB (XDR TB) were $22.8 \%, 13.6 \%$ and $10.4 \%$, respectively.

There was a significant $(p<0.005)$ association between cure and ADRs (Dela et al., 2017). Treatment outcomes were significantly better among those who experience ADRs. This is similar to a result found in a study done by Shin and the authors (2007) in Russia. A possible explanation is those patients who have side effects were followed more closely by TB providers and thereby adherent to treatment, thus increasing the likelihood of a favourable treatment outcome (Shin et al., 2007). ADRs were significantly associated with nontreatment adherence $(p=0.001)$ and defaulter outcome $(p=0.002)$. A similar result is shown in a study done by Vishakha and Sanjay (2013).

The most common side effect of anti TB drugs was GIT manifestations, and the least complication was dizziness. Adverse reactions did not negatively impact treatment outcomes among individuals who were adherent to treatment. There were significant relationships between ADRs and co-morbid disease ( $p$ $=0.0001, \mathrm{PR}=1.871,95 \% \mathrm{Cl}=1.370-2.555)$. However, ADR treatment status based on the given guidelines does not have a statistically significant relationship with the rate of TB treatment cure $(p=0.172, \mathrm{PR}=2.028$, $95 \% \mathrm{Cl}=0.582-7.071)$. Although most adverse drug reaction in this study was managed successfully and not significantly affected outcome therapy, clinician and pharmacist should put more attention because there were some patients developed life-threatening adverse drug reaction such as hypokalemia and nephrotoxicity (Asril I \& Soetikno V, 2019).

There are several limitations to this study. First, this kind of research is carried out retrospectively. Second, this study only evaluates patients from one MDR-TB referral hospital, where the total population reached is the respondent in this study by referring to random sampling techniques, and non-probability sampling can be carried out on a sample of 124 patients. Apart from the limitations of the study, we as researchers believe that our study provides important information about the side effects of second-line MDR-TB drugs, especially drugs that have a moderate to severe risk of side 
effects. Some of the drugs used for MDR-TB treatment cause psychiatric disorders. Psychosis has been reported as a side effect of using $\mathrm{INH}$, ethambutol, fluoroquinolones, and cyclosporine (CS). Depressive psychosis has been reported as a side effect mainly associated with CS. It has been reported that the incidence of severe psychiatric manifestations includes hallucinations, anxiety, depression, euphoria, behavioural disorders, and suicidal thoughts or attempts to use cyclosporine drugs (Arif et al., 2017).

\section{Acknowledgement}

The authors' thanks and appreciation are given to the Cempaka Putih Islamic Hospital in Central Jakarta, especially doctors, pharmaceutical personnel, and the hospital for assistance in licensing administration and support that has been provided during the research. We are also very grateful to the Director of the Islamic Hospital and the Head of the Pharmacy Installation for their excellent leadership.

\section{References}

Asril I, Soetikno V, A.P. (2019). Associations between the adverse drug reactions and the tuberculosis treatment dropout rates at the Cempaka Putih Islamic Hospital in Jakarta, Indonesia. Journal of Natural Science, Biology and Medicine, 10(3), 29-33

D. Pranger, A., W.C. Alffenaar, J., \& E. Aarnoutse, R. (2012). Fluoroquinolones, the Cornerstone of Treatment of DrugResistant Tuberculosis: A Pharmacokinetic and Pharmacodynamic Approach. Current Pharmaceutical Design. https://doi.org/10.2174/138161211797470200

Dela, A., Tank, N.K., Singh, A., \& Piparva, K. (2017). Adverse drug reactions and treatment outcome analysis of DOTS-plus therapy of MDR-TB patients at district tuberculosis centre: A four year retrospective study. Lung India, 34(6), 522. https://doi.org/10.4103/0970-2113.217569

El-Din, M.A.T., Halim, H.A. A.-E., \& El-Tantawy, A.M. (2015). Adverse reactions among patients being treated for multidrug resistant tuberculosis in Egypt from July 2006 to January 2009. Egyptian Journal of Chest Diseases and Tuberculosis, 64(3), 657-664. https://doi.org/10.1016/j.ejcdt.2015.05.011

Emil Ibrahim. (2018). Menyambut World TB Day 2018 : Peran $R S$ dalam Penanggulangan TB-MDR di Indonesia. Ditjen Yankes Kemenkes RI

Gualano, G., Mencarini, P., Musso, M., Mosti, S., Santangelo, L., Murachelli, S., Cannas, A., Di Caro, A., Navarra, A., Goletti, D., Girardi, E., \& Palmieri, F. (2019). Putting in harm to cure: Drug related adverse events do not affect outcome of patients receiving treatment for multidrug-resistant Tuberculosis. Experience from a tertiary hospital in Italy. PLOS ONE, 14(2), e0212948. https://doi.org/10.1371/journal.pone.0212948
Hair, J. F., Black, W.C., Babin, B.J., \& Anderson, R.E. (2010). Multivariate Data Analysis. In Vectors. https://doi.org/10.1016/j.ijpharm.2011.02.019

Jacobs, T., \& Ross, A. (2012). Adverse effects profile of multidrug-resistant tuberculosis treatment in a South African outpatient clinic. South African Family Practice, 54(6), 531539. https://doi.org/10.1080/20786204.2012.10874288

Kamso, P.S., Manaf, A., Alamiahnya, R., Tuberkulosis, U. P., Tuberkulosis, P., Mutu, P., \& Tb, L. (2011). Pedoman Nasional Penanggulangan Tuberkulosis edisi 2. Pedoman Nasional Penanggulangan Tuberkulosis Edisi 2

Kapadia V, Tripathi S, ST (2013). Analysis of 63 patients of MDR TB on DOTS plus regimen : An LG hospital, TB Unit, Ahmedabad experience . Gujarat Medical Journal, 68(2), 5557

Kemenkes RI. (2014). Pedoman-Tbnasional2014. In Pedoman Nasional Pengendalian Tuberkulosis

Lange, C., Dheda, K., Chesov, D., Mandalakas, A.M., Udwadia, Z., \& Horsburgh, C.R. (2019). Management of drug-resistant tuberculosis. The Lancet, 394(10202), 953-966. https://doi.org/10.1016/S0140-6736(19)31882-3

Merid, M.W., Gezie, L.D., Kassa, G.M., Muluneh, A.G., Akalu, T.Y., \& Yenit, M.K. (2019). Incidence and predictors of major adverse drug events among drug-resistant tuberculosis patients on second-line anti-tuberculosis treatment in Amhara regional state public hospitals; Ethiopia: a retrospective cohort study. BMC Infectious Diseases, 19(1), 286. https://doi.org/10.1186/s12879-019-3919-1

Mulu, W., Mekkonnen, D., Yimer, M., Admassu, A., \& Abera, B. (2015). Risk factors for multidrug resistant tuberculosis patients in Amhara National Regional State. African Health Sciences, 15(2), 368. https://doi.org/10.4314/ahs.v15i2.9

Pranger, A.D., van der Werf, T.S., Kosterink, J.G. W., \& Alffenaar, J.W.C. (2019). The Role of Fluoroquinolones in the Treatment of Tuberculosis in 2019. Drugs, 79(2), 161-171. https://doi.org/10.1007/s40265-018-1043-y

Reviono, Kusnanto, Vicky Eko, Helena Pakiding, \& Nurwidiasih, D. (2014). Multidrug Resistant Tuberculosis (MDR-TB): Tinjauan Epidemiologi dan Faktor Risiko Efek Samping Obat Anti Tuberkulosis. Majalah Kedokteran Bandung, 46(4), 189-196

Schmit, K.M., Wansaula, Z., Pratt, R., Price, S.F., \& Langer, A.J. (2017). Tuberculosis - United States, 2016. MMWR. Morbidity and Mortality Weekly Report. https://doi.org/10.15585/mmwr.mm6611a2

Shin, S.S., Pasechnikov, A.D., Gelmanova, I.Y., Peremitin, G.G., Strelis, A.K., Mishustin, S., Barnashov, A., Karpeichik, Y., Andreev, Y.G., Golubchikova, V.T., Tonkel, T.P., Yanova, G.V., Yedilbayev, A., Rich, M.L., Mukherjee, J.S., Furin, J.J., Atwood, S., Farmer, P.E., \& Keshavjee, S. (2007). Adverse reactions among patients being treated for MDR-TB in Tomsk, Russia. The International Journal of Tuberculosis and Lung Disease: The Official Journal of the International Union against Tuberculosis and Lung Disease, 11(12), 1314-1320. http://www.ncbi.nlm.nih.gov/pubmed/18034952 
Tae Won Yang, Md., , Hyun Oh Park, Md., , Ha Nee Jang, Md., , Jun Ho Yang, Md., Sung Hwan Kim, Md., , Seong Ho Moon, Md., , Joung Hun Byun, Md., , Chung Eun Lee, Md., Jong Woo Kim, Md., \& , Dong Hun Kang, Md. (2017). Side effects associated with the treatment of multidrug-resistant tuberculosis at a tuberculosis referral hospital in South Korea A retrospective study. Medicine (United States), 96(28), e7482

Umi Fatmawati, T.K. (2019). Characteristics and the Side Effects of New MDR-TB Treatment in the Dr. Soetomo Hospital during 2016. Jurnal Respirasi, 3(3), 67

WHO, W. H. O. (2016). WHO treatment guidelines for drugresistant tuberculosis: 2016 update. Who. https://doi.org/WHO/HTM/TB/2016.04

Widiastuti, E., Subronto, Y., \& Promono, D. (2017). Determinan Kejadian multi drug resistant tuberculosis di rumah sakit Dr. Sardjito Yogyakarta. Berita Kodekteran Masyarakat, 33(7), 325-330

Yang, T.W., Park, H.O., Jang, H.N., Yang, J.H., Kim, S.H., Moon, S.H., Byun, J.H., Lee, C. E., Kim, J.W., \& Kang, D.H. (2017). Side effects associated with the treatment of multidrug-resistant tuberculosis at a tuberculosis referral hospital in South Korea. Medicine (United States). https://doi.org/10.1097/MD.0000000000007482

Yates, T.A., Tomlinson, L.A., Bhaskaran, K., Langan, S., Thomas, S., Smeeth, L., \& Douglas, I. J. (2017). Lansoprazole use and tuberculosis incidence in the United Kingdom Clinical Practice Research Datalink: A population based cohort. PLOS Medicine. https://doi.org/10.1371/journal.pmed.1002457 